\title{
29. THORIUM AND URANIUM ISOTOPES IN UPPER PLEISTOCENE SEDIMENTS OF ODP SITES 645 (BAFFIN BAY), 646, AND 647 (LABRADOR SEA)1
}

\author{
Christiane Causse ${ }^{2}$ and Claude Hillaire-Marcel ${ }^{2,3}$
}

\begin{abstract}
Concentrations and activity ratios of uranium and thorium isotopes $\left({ }^{234} \mathrm{U} /{ }^{238} \mathrm{U},{ }^{230} \mathrm{Th} /{ }^{232} \mathrm{Th}\right)$ were determined at about 5-m intervals through the composite top 22-m sequence of Ocean Drilling Program (ODP) Hole 645 in Baffin Bay and, in the Labrador Sea, at 1-m intervals through the top $11 \mathrm{~m}$ of Core 84-030-003 (TWC and P) collected by the Hudson during a preliminary survey of Site 647 , and also at about $2-\mathrm{m}$ intervals through the composite top 22-m sequence of Hole 646 . In the Labrador Sea, surficial sediments show unsupported ${ }^{230} \mathrm{Th}$ having a ${ }^{230} \mathrm{Th} /{ }^{234} \mathrm{U}$ activity ratio of about 3. At Site 647 , a regular decrease in the ${ }^{230} \mathrm{Th} /{ }^{232} \mathrm{Th}$ activity ratio was observed downcore from about 1.2 (at $1 \mathrm{mbsf}$ ) to about 0.4 (at $\sim 8 \mathrm{mbsf}$ ), through a sequence spanning over ${ }^{18} \mathrm{O}$ stages 2 through 8 . The correlative thorium/uranium chronology and ${ }^{18} \mathrm{O}$ stratigraphy indicate relatively constant sedimentation rates throughout the sequence. At Site 646, down Greenland slope, and at Site 645, in Baffin Bay, highly variable uranium and thorium concentrations and isotopic ratios were observed in relation to highly variable sedimentation rates. As a whole, the lower ${ }^{230} \mathrm{Th}$-excess observed in Baffin Bay records is indicative of very high absolute sedimentation rates in comparison with those of the Labrador Sea. These rates are confirmed by the ${ }^{18} \mathrm{O}$-stratigraphy and a few AMS ${ }^{14} \mathrm{C}$ controls on handpicked foraminifers. At both Labrador Sea sites, a clear indication of an initial ${ }^{230} \mathrm{Th}$-excess (over the ${ }^{230} \mathrm{Th}$-rain from the water column) was found.
\end{abstract}

\section{INTRODUCTION}

Since the early work of Piggot and Urry (1939, 1942), several authors developed the ${ }^{230} \mathrm{Th}$-excess method for studying deep sea sediments. Picciotto and Wilgain (1954), then Goldberg and Koide $(1958,1962)$, showed that the downcore-decreasing ${ }^{230} \mathrm{Th} /$ ${ }^{232} \mathrm{Th}$ ratio could be used to estimate sedimentation rates. This approach is based on the presence of a significant amount of ${ }^{234} \mathrm{U}$ and unsupported ${ }^{230} \mathrm{Th}$ in surficial sediments, produced by the decay of uranium in the water column. Its validity depends on the fulfillment of several prerequisites, of which the most important are:

1. A homogeneous source of detrital particles during the sedimentation period under consideration (e.g., clays with constant "initial" uranium and thorium concentrations and isotopic ratios).

2. A constant production of ${ }^{230} \mathrm{Th}$ in the water column from its parent isotope $\left({ }^{234} \mathrm{U}\right.$; i.e., a constant uranium-content in sea water; see Turekian and Chan, 1971b; and Ku et al., 1977).

3. A constant rate of speciation (removal/precipitation) of thorium (which in turn implies a constant planktonic activity; see Fisher et al., 1987).

4. A negligible or constant uptake of uranium in the surficial sediments (with biogenic minerals, see Holmes et al., 1968; $\mathrm{Ku}, 1966$; and with organic matter, see Veeh, 1967; Turekian and Bertine, 1971a; Baturin, 1973, etc.).

When these conditions are encountered, surficial sediments show an excess of ${ }^{230} \mathrm{Th}$ activity over ${ }^{234} \mathrm{U}$ as an effect of the "thorium rain" from the water column and possibly as a conse-

\footnotetext{
${ }^{1}$ Srivastava, S. P., Arthur, M., Clement, B., 1989. Proc. ODP, Sci. Results, 105: College Station, TX (Ocean Drilling Program).

2 Laboratoire de Géologie du Quaternaire, CNRS Case 907. Campus de Luminy, 13 288, Marseille Cédex 9, France.

${ }^{3}$ GEOTOP, Université du Québec à Montréal, CP 8888, , Succ. A, Montréal, Québec H3C 3P8, Canada.
}

quence of an "initial" excess of ${ }^{230} \mathrm{Th}$ in detrital particles originating from intensively leached soil profiles on surrounding continents (Fig. 1; see Rosholt et al., 1966; Moreira-Nordemann, 1980). Therefore, the decay of the unsupported ${ }^{230} \mathrm{Th}$ through time allows one to determine the sedimentation rates. Unfortunately, ideal conditions are rarely encountered (Coch-

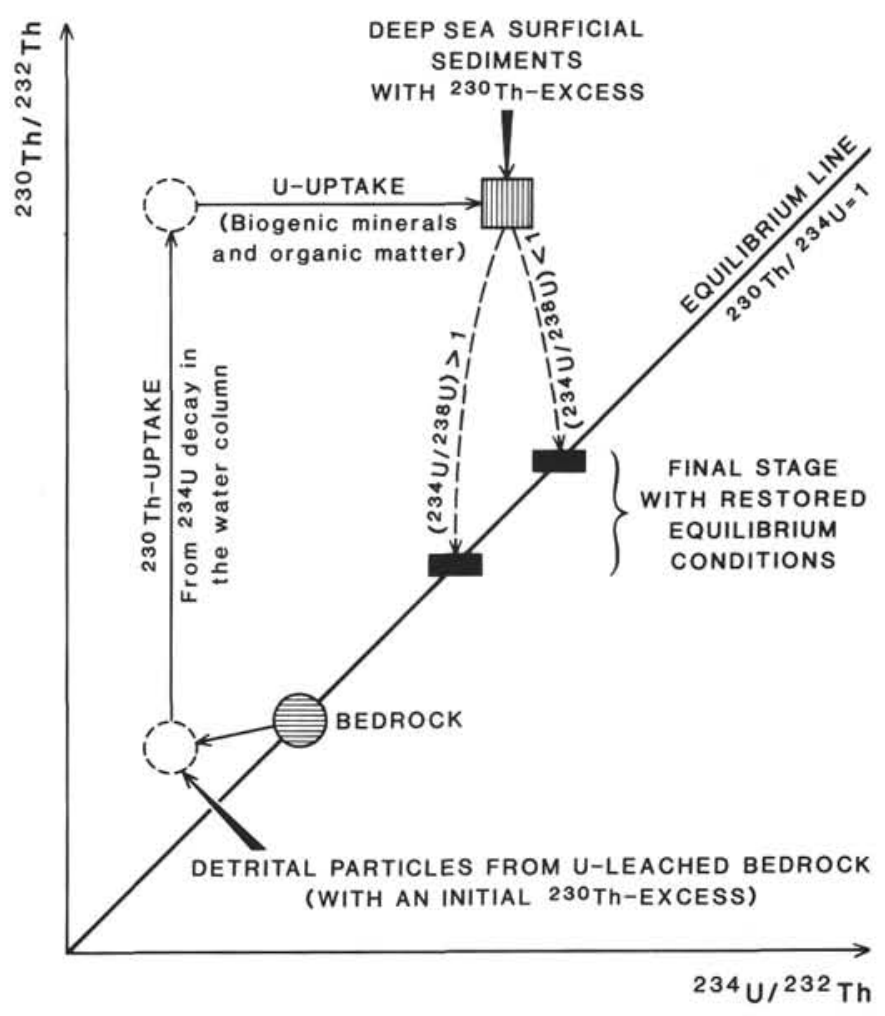

Figure 1. Sketch of ${ }^{230} \mathrm{Th}$ accumulation and decay in deep-sea sediments. 
ran, 1982; Lalou, 1982; and other review papers in Ivanovich and Harmon, 1982) and, in most cases, the excess-thorium method can simply provide empirical first-order information about sedimentation rates. Recently, precise time-marks were established for $\delta^{18} \mathrm{O}$ stage boundaries, and generally the ${ }^{18} \mathrm{O}$ stratigraphy provides better interpolations of deep-sea sedimentation rates. However, in the Labrador Sea and Baffin Bay basins, large-amplitude ${ }^{18} \mathrm{O}$ changes (Hillaire-Marcel et al., and Aksu et al., this volume) in relation to direct meltwater influx from surrounding ice caps do not unequivocally correlate with the "open ocean" ${ }^{18} \mathrm{O}$ stratigraphy; furthermore, access to time-dependent data beyond the ${ }^{14} \mathrm{C}$-method limits was of a great interest. On these premises, we undertook a preliminary study of uranium and thorium isotopes in cores from ODP Sites 645 (Baffin Bay), 646, and 647 (Labrador Sea; Fig. 2).

\section{SAMPLING AND METHODS}

Leg 105 Site locations in Baffin Bay and in the Labrador Sea are indicated in Figure 2. From ODP Hole 645 , in Baffin Bay, four $\sim 2-0 \mathrm{~cm}^{3}$ samples were analyzed and two were duplicated. These samples were collected at $\sim 5-\mathrm{m}$ intervals through the composite top $22 \mathrm{~m}$ sequence. From the Labrador Sea, 12 samples taken at $\sim 1$-m intervals through the top $11 \mathrm{~m}$ of Core 84-030-003 (TWC and PC) collected by the Hudson during a preliminary survey of Site 647 , as well as 12 samples at $\sim 2$-m intervals through the composite top 22 -m sequence of Hole 646 , were analyzed. Eleven of the latter were cut off the core sections of Hole 646B.

In all samples, the $<120 \mu \mathrm{m}$ fraction was separated by sieving after shaking in distilled water. The fine fraction was then completely dissolved, first in aqua regia, and then in a mixture of perchloric and hydrofluoric acids. Uranium and thorium isotopes present in the $\mathrm{HCl} 6 \mathrm{~N}$ solution obtained are preconcentrated by coprecipitation with iron and aluminium hydroxides. Separation of uranium isotopes was made on anion exchange column (Dowex AG1X8, 200-400 mesh), and further purification was conducted by selective extraction on organic solvents: iron is removed by hexone from the $\mathrm{HCl} 6 \mathrm{~N}$ solution, and specific extraction of heavy elements by thenoyltrifluoroacetone (TTA) in $4 \mathrm{M}$ solution in benzene from a nitric solution at $\mathrm{pH} 3$ usually achieves a suitable degree of purification. Before the separation of thorium isotopes on the cation exchange column (Dowex 50WX8, 200-400 mesh), most of the aluminium was removed by dissolution in $3 \mathrm{~N} \mathrm{NaOH}$ solution. Final purification was conducted in the TTA-benzene solution from a nitric solution at $\mathrm{pH} 1$. Uranium and thorium sources were electrodeposited from an ethyl alcohol solution in slightly acid form. Resolution of alpha spectra (detectors were silicon surface barrier-type, $100 \mu \mathrm{m}$ depletion depth, and $350 \mathrm{~mm}^{2}$ area) was better than $50 \mathrm{KeV}$.

This chemical procedure is relatively conventional, as can be concluded from Lally's review paper (1982). A less usual feature is the choice of the spike: the conventional ${ }^{232} \mathrm{U}^{228} \mathrm{Th}$ couple at secular equilibrium was added to a recent ${ }^{234} \mathrm{Th}$ preparation. The ${ }^{234} \mathrm{Th}$ is a natural radioactive isotope, which is thus present in samples, but there is no problem of interference with the ${ }^{234} \mathrm{Th}$ activity of the sample because ${ }^{234} \mathrm{Th}$ is a $\beta$-emitter, and a large excess (three or four orders of magnitude) is used.

The ${ }^{234} \mathrm{Th}$ is isolated from the uranium solution once it has been cleaned of its thorium isotopes, and then allowed to produce its daughters. After two or three months, the ${ }^{234} \mathrm{Th} /{ }^{238} \mathrm{U}$ activity ratio is high enough to obtain a preparation usable for 40 or 50 samples. This ${ }^{234} \mathrm{Th}$ solution, checked for its null alpha activity, is evaporated to dryness in a pyrex erlen into which the ${ }^{232} \mathrm{U}-{ }^{228} \mathrm{Th}$ alpha spike has been poured. After homogeneization under ultrasonic conditions, the triple spike is ready to be introduced at the beginning of each analysis. One weighed quantity of $\sim 100 \mu \mathrm{L}$ (micropipetted) is allowed to dry at laboratory temperature on a platinum disk and is used as an external reference for each thorium source. This reference disk is $\beta$-counted at least 10 times, and at least 600,000 counts are counted each time. The $\beta$-activity of each thorium source is checked twice, with a total measured activity greater than 600,000 counts. $\beta$-activity is registered with a silicon surface barrier detector partially depleted ( $300 \mu \mathrm{m}$ depth) and protected from ambient radioactivity by a lead shield. The background is equal to $2 \mathrm{cpm}$. Under these conditions, the thorium chemical efficiency is determined with a standard deviation equal to $2 \%$. The source geometry is constant, as ensured by the electrodeposition. The alpha counting effi- ciency, necessary for knowing the total efficiency of the thorium, was determined by analyses of uraninite in secular equilibrium for ${ }^{238} \mathrm{U}$ ${ }^{234} \mathrm{U}-{ }^{230} \mathrm{Th}$ isotopes.

This method presents one disadvantage: one must prepare the spike every two or three months. But two advantages are significant: (1) the risk of a wrong thorium efficiency calculated in the case of disequilibrium between ${ }^{232} \mathrm{Th}$ and ${ }^{228} \mathrm{Th}$ is eliminated and (2) even in the case of equilibrium greater accuracy is obtained for thorium efficiency determination.

\section{URANIUM AND THORIUM ISOTOPES IN LABRADOR SEA}

At Site 647 in south-central Labrador Sea (Table 1), uniform ${ }^{232} \mathrm{Th}$ concentrations $(X=4.89 \pm 0.62 \mu \mathrm{g} / \mathrm{g})$ are observed downcore, indicating a homogeneous source of detrital particles. The uranium uptake by organic matter and biogenic minerals was apparently low: an average uranium concentration of $0.62 \pm$ $0.08 \mu \mathrm{g} / \mathrm{g}$ characterizes the studied sequence, with two exceptions (UQT-532 and UQT-545; Table 1). These two samples show higher proportions of uranium $(>1 \mu \mathrm{g} / \mathrm{g})$. Their ${ }^{234} \mathrm{U} /$ ${ }^{238} \mathrm{U}$ activity ratio (respectively $1.07 \pm 0.02$ and $1.16 \pm 0.03$ ) confirms the uranium uptake from seawater. Actually, all the other samples show ${ }^{234} U /{ }^{238} U$ ratios $<1(X=0.94 \pm 0.05)$, typical of marine clays that have undergone preferential ${ }^{234} \mathrm{U}$ leaching during sedimentation. As expected, the ${ }^{230} \mathrm{Th} /{ }^{232} \mathrm{Th}$ activity ratio decreases regularly downcore (Figs. 3 and 4). Very minor changes in the sedimentation rate may be inferred between isotopic stages 7 and 5 for an interpolated average value of $\sim 5 \times 10^{-3} \mathrm{~cm} / \mathrm{yr}$.

At Site 646, a more irregular pattern is observed (Table 2). This can be seen, for example, by the ${ }^{238} \mathrm{U} /{ }^{232} \mathrm{Th}$ activity ratio variations downcore $(X=0.66 \pm 0.26)$ and also by the wide fluctuations in the ${ }^{230} \mathrm{Th}$-excess values (above ${ }^{234} \mathrm{U}$; Figs. 5 and 6 ). By comparison with Site 647 , the latter is also characterized by lower ${ }^{232} \mathrm{Th}$ concentrations $(X=3.3 \pm 0.6 \mu \mathrm{g} / \mathrm{g})$ and a proportionally higher uranium uptake with ${ }^{234} U /{ }^{238} U$ activity ratios more often exceeding the equilibrium value of 1 . As a whole, sedimentation rate changes from $\sim 5 \times 10^{-3}$ to $\sim 13 \times 10^{-3}$ $\mathrm{cm} / \mathrm{yr}$, about a mean value of $\sim 9 \times 10^{-3} \mathrm{~cm} / \mathrm{yr}$ (Fig. 7 and Table 3), may be calculated using time-marks obtained from the ${ }^{18} \mathrm{O}$-stratigraphy (Aksu et al., this volume) and assuming an initial ${ }^{230} \mathrm{Th} /{ }^{232} \mathrm{Th}$ ratio of about 0.36 in the detrital particles before any ${ }^{230} \mathrm{Th}$ increment from the "thorium rain." This initial value equal to 0.36 is suggested by the lowest isotopic ratios observed in the regional deep-sea clays, notably those of Baffin Bay (see below: Sample UQT-490; Table 4), where very high sedimentation rates result in an almost negligible ${ }^{230} \mathrm{Th}$ uptake from the ${ }^{230}$ Th-rain.

At both sites, some similar geochemical processes appear. All samples having relatively high proportions of uranium (vs. ${ }^{232} \mathrm{Th}$ ) show correlatively higher ${ }^{234} \mathrm{U} /{ }^{238} \mathrm{U}$ ratios that occasionally (e.g., UQT-532) reach the typical value of seawater $(\sim 1.15$; Thurber, 1962). In such samples, uranium uptake from seawater (with organic matter or biogenic minerals) can be inferred. Indeed, these differ from all other samples with a uranium content essentially related to that of the detrital particles: these samples have ${ }^{234} \mathrm{U} /{ }^{238} \mathrm{U}$ activity ratios lower than 1.0 , in a few cases, as low as $\sim 0.84$. The ${ }^{234} U$-preferential leaching certainly occurs here when the clay particles are in suspension and during the sedimentation phase, rather than during their early continental genesis and history, considering the climate in the surrounding continents, which is cold and unfavorable for efficient leaching processes. Because of the large sampling intervals, it is hazardous to correlate the high uranium-content samples with climatic episodes as a whole. However, the highest value falls into isotopic stage 5 (according to ${ }^{18} \mathrm{O}$ data; de Vernal and Hillaire-Marcel, 1987), i.e., into an interglacial period when higher primary productivity and organic sedimentation may be ex- 


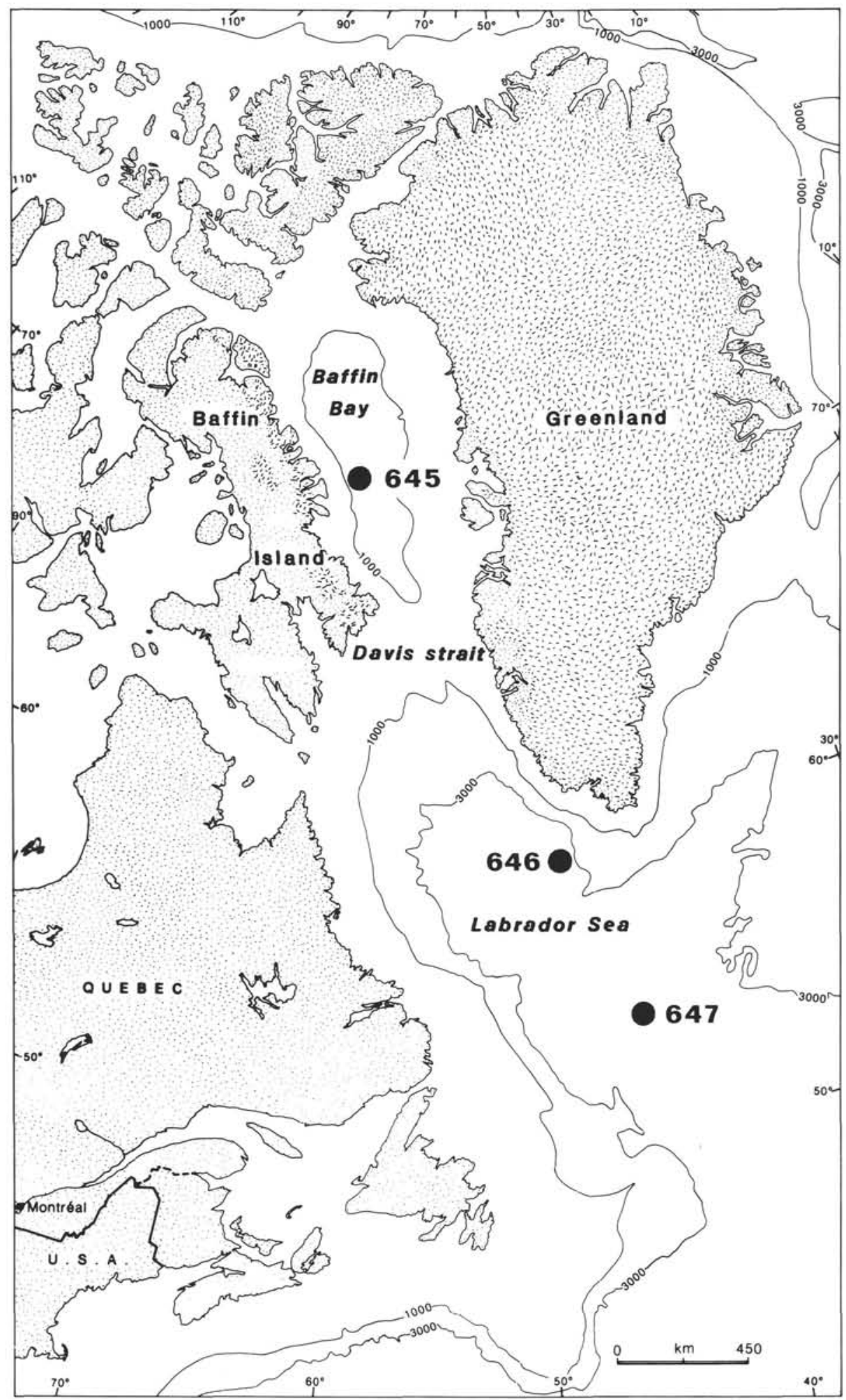

Figure 2. Location map of Sites 645, 646, and 647.

pected. This trend apparently contradicts that observed by Kalil (1976).

Another characteristic of the surficial sediments in the Labrador Sea may also be mentioned. At both sites, a large difference exists between the ${ }^{230} \mathrm{Th}$-excess ${ }^{230} \mathrm{Th}$ over equilibrium with $\left.{ }^{234} \mathrm{U}\right)$ measured in surficial sediments $(\sim 2.8 \mathrm{dpm} / \mathrm{cm}$ at Site 646 and $\sim 2.6 \mathrm{dpm} / \mathrm{cm}$ at Site 647 ) and the expected theoretical value. The latter can be calculated from the ${ }^{230} \mathrm{Th}$ production in the overlying water column and the average sedimentation rates (for Site $646, \sim 9 \mathrm{~cm} \times 10^{-3} \mathrm{yr}$; for Site $647, \sim 5 \mathrm{~cm} \times 10^{-3}$ yr) interpolated above from the ${ }^{18} \mathrm{O}$-stratigraphy. The theoretical ${ }^{230} \mathrm{Th}$-excess calculates to $\sim 0.85 \mathrm{dpm} / \mathrm{cm}$ and $\sim 1.7 \mathrm{dpm} / \mathrm{cm}$, 
Table 1. Thorium and uranium concentrations and isotope activity ratios at Site 647.

\begin{tabular}{|c|c|c|c|c|c|c|c|c|c|}
\hline $\begin{array}{l}\text { Field }^{1} \\
\text { number }\end{array}$ & $\begin{array}{l}\text { Laboratory } \\
\text { number }\end{array}$ & $\begin{array}{l}{ }^{232} \mathrm{Th} \\
(\mu \mathrm{g} / \mathrm{g})\end{array}$ & $\begin{array}{l}{ }^{238} \mathrm{U} \\
(\mu \mathrm{g} / \mathrm{g})\end{array}$ & $\frac{{ }^{234} U}{{ }^{238} U}$ & $\frac{{ }^{238} \mathrm{U}}{{ }^{232} \mathrm{Th}}$ & $\frac{{ }^{230} \mathrm{Th}}{{ }^{232} \mathrm{Th}}$ & $\frac{{ }^{234} \mathrm{U}}{{ }^{232} \mathrm{Th}}$ & $\begin{array}{c}{ }^{230} \mathrm{Th} \\
(\mathrm{dpm} / \mathrm{g})\end{array}$ & $\begin{array}{c}{ }^{234} \mathrm{U} \\
(\mathrm{dpm} / \mathrm{g})\end{array}$ \\
\hline \multirow[t]{2}{*}{$3 \mathrm{~T}-101 / 103$} & UQT-530 & 4.67 & 0.73 & 0.92 & 0.47 & 1.24 & 0.43 & 1.42 & 0.50 \\
\hline & & \pm 0.20 & \pm 0.02 & \pm 0.03 & \pm 0.02 & \pm 0.03 & 0.02 & \pm 0.06 & \pm 0.01 \\
\hline \multirow[t]{2}{*}{$3 T-186 / 188$} & UQT-531 & 4.90 & 0.67 & 0.97 & 0.41 & 1.08 & 0.40 & 1.30 & 0.48 \\
\hline & & \pm 0.30 & \pm 0.02 & \pm 0.03 & \pm 0.03 & \pm 0.03 & \pm 0.03 & \pm 0.08 & \pm 0.01 \\
\hline \multirow[t]{2}{*}{$3 P-103 / 105$} & UQT-532 & 5.03 & 1.49 & 1.16 & 0.90 & 0.95 & 1.04 & 1.18 & 1.29 \\
\hline & & \pm 0.35 & \pm 0.04 & \pm 0.03 & \pm 0.07 & \pm 0.03 & \pm 0.08 & \pm 0.08 & \pm 0.03 \\
\hline \multirow[t]{2}{*}{$3 P-204 / 206$} & UQT-533 & 4.15 & 0.55 & 1.00 & 0.40 & 0.85 & 0.40 & 0.87 & 0.41 \\
\hline & & \pm 0.21 & \pm 0.01 & \pm 0.03 & \pm 0.02 & \pm 0.03 & \pm 0.02 & \pm 0.04 & \pm 0.01 \\
\hline \multirow[t]{2}{*}{$3 P-302 / 304$} & UQT-534 & 5.70 & 0.76 & 0.89 & 0.40 & 0.63 & 0.36 & 0.88 & 0.51 \\
\hline & & \pm 0.17 & \pm 0.01 & \pm 0.02 & \pm 0.01 & \pm 0.01 & \pm 0.01 & \pm 0.03 & \pm 0.01 \\
\hline \multirow[t]{2}{*}{$3 \mathrm{P}-400 / 402$} & UQT-535 & 4.27 & 0.53 & 0.94 & 0.38 & 0.70 & 0.36 & 0.74 & 0.38 \\
\hline & & \pm 0.23 & \pm 0.01 & \pm 0.03 & \pm 0.02 & \pm 0.02 & \pm 0.02 & \pm 0.04 & \pm 0.01 \\
\hline \multirow[t]{2}{*}{$3 P-500 / 502$} & UQT-543 & 4.73 & 0.58 & 0.90 & 0.37 & 0.54 & 0.33 & 0.63 & 0.39 \\
\hline & & \pm 0.13 & \pm 0.01 & \pm 0.03 & \pm 0.01 & \pm 0.01 & \pm 0.01 & \pm 0.02 & \pm 0.01 \\
\hline \multirow[t]{2}{*}{$3 \mathrm{P}-603 / 605$} & UQT-544 & 3.93 & 0.53 & 0.84 & 0.41 & 0.53 & 0.34 & 0.51 & 0.33 \\
\hline & & \pm 0.10 & \pm 0.01 & \pm 0.03 & \pm 0.02 & \pm 0.01 & \pm 0.01 & \pm 0.01 & \pm 0.01 \\
\hline \multirow[t]{2}{*}{ 3P-696/698 } & UQT-545 & 5.49 & 1.07 & 1.06 & 0.59 & 0.54 & 0.63 & 0.72 & 0.85 \\
\hline & & \pm 0.16 & \pm 0.02 & \pm 0.02 & \pm 0.02 & \pm 0.01 & \pm 0.02 & \pm 0.02 & \pm 0.01 \\
\hline \multirow[t]{2}{*}{$3 \mathrm{P}-801 / 803$} & UQT-546 & 4.42 & 0.56 & 0.99 & 0.38 & 0.42 & 0.38 & 0.46 & 0.41 \\
\hline & & \pm 0.13 & \pm 0.01 & \pm 0.03 & \pm 0.01 & \pm 0.01 & \pm 0.01 & \pm 0.02 & \pm 0.01 \\
\hline \multirow[t]{2}{*}{ 3P-911/913 } & UQT-547 & 5.49 & 0.66 & 0.97 & 0.36 & 0.43 & 0.35 & 0.57 & 0.48 \\
\hline & & \pm 0.16 & \pm 0.01 & \pm 0.03 & \pm 0.01 & \pm 0.01 & \pm 0.01 & \pm 0.02 & \pm 0.01 \\
\hline \multirow[t]{2}{*}{$3 \mathrm{P}-1008 / 10$} & UQT-548 & 5.92 & 0.70 & 0.94 & 0.36 & 0.44 & 0.34 & 0.64 & 0.49 \\
\hline & & \pm 0.18 & \pm 0.02 & \pm 0.04 & \pm 0.02 & \pm 0.01 & \pm 0.02 & \pm 0.02 & \pm 0.02 \\
\hline
\end{tabular}

${ }^{1} \mathrm{~T}=$ Trigger weight core; $\mathrm{P}=$ Piston core; sampling interval in centimeters below seafloor. Error data represent one $\sigma$ from counting statistics.

respectively, at Sites 646 and 647 . These values are based on the ${ }^{230} \mathrm{Th}$ "classical" scavenging rate of

$$
2.2 \mathrm{dpm} / D \mathrm{~km} / \mathrm{cm} \times 10^{3} \mathrm{yr}
$$

where $D=$ the water depth (in kilometers)(see Lalou, 1985). The ${ }^{230} \mathrm{Th}$-excess over that accounted by the decay of ${ }^{234} \mathrm{U}$ in the water column must be introduced into the sediment without the parent isotope, i.e., without uranium uptaking. Two probably complementary causes can be invoked. Beyond the particle ${ }^{230} \mathrm{Th} /$ ${ }^{234} \mathrm{U}$ disequilibrium due to uranium leaching, a large proportion of unsupported ${ }^{230} \mathrm{Th}$ is probably incorporated into the sediment as an effect of organic activity. Algae (Mann and Fyfe, 1984) and bacteria (Beveridge et al., 1983) are known to concentrate uranium from ambient water. Recently, Fisher et al. (1987) also showed significant thorium uptake by nano- and picoplankton. Plankton and their debris are oxidized while sinking and depositing. When ${ }^{230} \mathrm{Th}$ remains trapped and accumulates within the sediment, uranium may still be released into the ambient water. Consequently, surficial sediments may receive a ${ }^{230} \mathrm{Th}$-excess above that due to the classical ${ }^{230} \mathrm{Th}$-rain from the decay of dissolved ${ }^{234} \mathrm{U}$ in the water column. The relative weight of this bio-induced ${ }^{230} \mathrm{Th}$ accumulation increases where the water column depth decreases and also at places where the primary productivity increases: i.e., larger anomalies should be observed in shallower sites and near neritic environments. Moreover, because turbidity as a whole is higher in marginal basins compared to "open oceans," ${ }^{230} \mathrm{Th}$ scavenging rates should increase proportionally. A horizontal flux of ${ }^{230} \mathrm{Th}$, from the latter to the former, should be the consequence of this difference. Beyond other considerations (see Cochran, 1982, for a review of literature), this phenomenon could account at least for some negative anomalies observed in ${ }^{230} \mathrm{Th}$ excesses in open oceans and, in this case, for the positive anomaly of the Labrador Sea surficial sediments. Both effects, i.e., the bio-induced ${ }^{230} \mathrm{Th}$ accumulation and the ${ }^{230} \mathrm{Th}$ scavenging rates, should increase in shallower basins. In fact, this is the case in the Labrador Sea, where the ac- tual ${ }^{230} \mathrm{Th}$-excess in surficial sediments vs. the theoretical value increases from a ratio of $\sim 1.5$ at Site 647 in the central Labrador Sea (depth $\sim 3850 \mathrm{~m}$ ) to $\sim 3.3$ at Site 646 , on the Greenland slope (depth $\sim 3450 \mathrm{~m}$ ). As a result, any attempt to calculate sedimentation rates from measured ${ }^{230} \mathrm{Th}$-excesses and theoretical ${ }^{230} \mathrm{Th}$-rains in the water columns fails. According to Lalou (1985), the ${ }^{230} \mathrm{Th}$ anomalies described above are considered to be uniform through time at any specific site. Hence, when few time controls exist (e.g., through ${ }^{18} \mathrm{O}$-stage boundaries), short-term changes in the sedimentation rate can be determined from ${ }^{230} \mathrm{Th}$ excess fluctuations, the mean sedimentation rate being provided otherwise. However, we would like to add a note of caution: in marine basins such as the Labrador Sea, where primary productivity experienced significant changes in relation to glacial/interglacial successions (de Vernal and Hillaire-Marcel, 1987), the bio-induced ${ }^{230} \mathrm{Th}$-excess may have changed drastically through time. Consequently, the latter might here be an indicator of paleoproductivities rather than of sedimentation rates.

\section{URANIUM AND THORIUM ISOTOPES IN BAFFIN BAY}

At Site 645 , the sediments are characterized by ${ }^{232} \mathrm{Th}$ concentrations as high as $17 \mu \mathrm{g} / \mathrm{g}$ (Sample UQT-490; Table 4). Although deep-sea clays are known to have an average thorium content of $\sim 10 \mu \mathrm{g} / \mathrm{g}$ (Lalou, 1982), we have already seen that the Labrador sediments are much poorer in thorium (with concentrations of $\sim 3$ to $5 \mu \mathrm{g} / \mathrm{g}$ ). From this viewpoint, the sedimentation history of Baffin Bay has to be considered independently from that of the Labrador Sea. Relatively high thorium contents are also observed in shallow marginal environments of the Laurentide Ice Sheet (e.g., in Lake Deschaillons varves of St. Lawrence Lowland; see Hillaire-Marcel and Causse, 1987), where the fine fraction originates from the glacial floor. On sedimentological grounds, the Baffin Bay sediments show large similarities with the latter: notably their coarseness and mineralogical composition (see Aksu and Piper, 1979). 


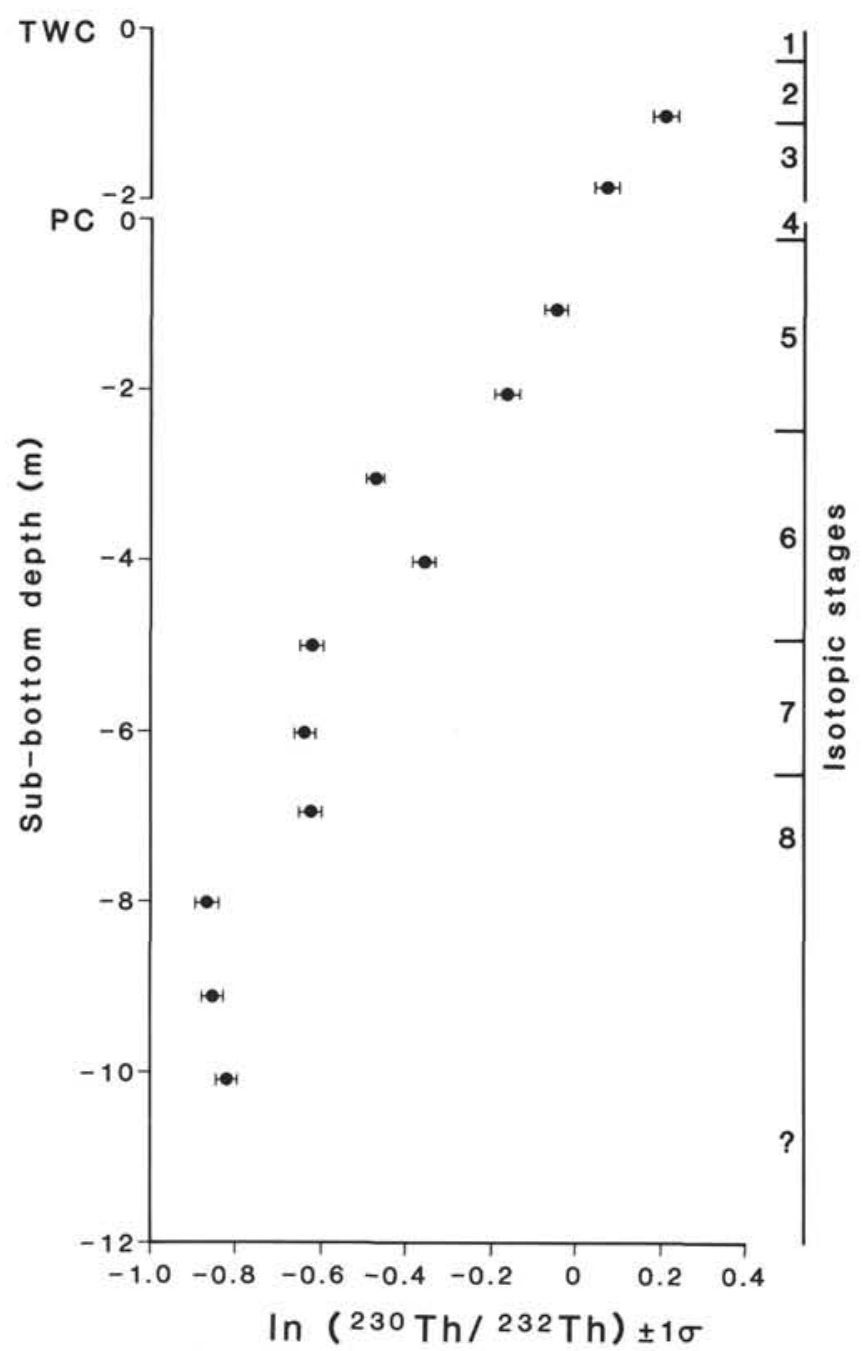

Figure 3. The ${ }^{230} \mathrm{Th} /{ }^{232} \mathrm{Th}$ activity ratios decrease down Core HU-84030-003, collected during the Hudson Site 647 survey.

As a whole, uranium uptake by surficial sediments seems negligible: uranium/thorium mass ratios of 0.1 to 0.2 were measured. Whereas the very modern surficial sediments show a ${ }^{230} \mathrm{Th}$-excess $\left(\sim 2.5 \mathrm{dpm} / \mathrm{g}\right.$ above ${ }^{234} \mathrm{U}$ activity; Sample UQT675) not unlike that observed on the Greenland slope in the Labrador Sea, all other samples are characterized by ${ }^{230} \mathrm{Th} /{ }^{234} \mathrm{U}$ activity ratios near the equilibrium value (within the standard deviation; Fig. 8). This difference may be attributed to the very large sedimentation rate change that occurred there at the Holocene glacial/interglacial transition. Actually, in most piston cores collected in the deepest part of the Bay, the post-glacial sediments were rarely recovered and they were represented by no more than a few inches in trigger-weight cores. On the contrary, a high pre-Holocene mean sedimentation rate of $\sim 8$ to $10 \times$ $10^{-3} \mathrm{~cm} / \mathrm{yr}$ was interpolated between ${ }^{18} \mathrm{O}$-stage boundaries and a few ${ }^{14} \mathrm{C}$ (AMS) ages of foraminifers (de Vernal et al., 1987; Hillaire-Marcel et al., this volume). During most of the sedimentary episode sampled here, the primary productivity was extremely low, if not nonexistent, in this basin notably because of a dense sea-ice cover (de Vernal, 1986). As a result, the only source of ${ }^{230} \mathrm{Th}$-excess at the surface of the sediments was the ${ }^{230} \mathrm{Th}$-rain from the decay of dissolved ${ }^{234} \mathrm{U}$ in the water column. Using the ${ }^{230} \mathrm{Th}$-scavenging rate formula mentioned above, and assuming a sedimentation rate of $\sim 10 \times 10^{-3} \mathrm{~cm} / \mathrm{yr}$, the ${ }^{230} \mathrm{Th}-$ excess activity (above that of ${ }^{234} U$ ) in the surficial sediments when deposited was $\sim 0.5 \mathrm{dpm} / \mathrm{cm}^{3}$. Because ${ }^{234} \mathrm{U}$-activities of $\sim 4.5 \mathrm{dpm} / \mathrm{cm}^{3}$ are actually measured in the sediments, the ${ }^{230}$ Th-excess did not originally exceed about $10 \%$ (above the ${ }^{234} \mathrm{U}$-supported thorium 230 ). Within less than $10,000 \mathrm{yr}$, this excess decreased to a value falling within the analytical standard deviation around the equilibrium value. We have to conclude that, unfortunately, the thorium/uranium method is of no help here in establishing sedimentation rate changes through time, and a fortiori that it cannot provide any assessment of the absolute rate values. One can conclude that sedimentation rates (from $\sim 8$ to $20 \mathrm{~cm} \times 10^{-3} \mathrm{yr}$; Hillaire-Marcel et al., this volume) were high enough to prevent any significant accumulation of unsupported ${ }^{230} \mathrm{Th}$, at least until the last glacial/interglacial transition.

\section{CONCLUSIONS}

This study confirms, once again, that uranium and thorium concentrations and isotopic ratios often do not provide direct time controls in deep-sea sediments (this statement is certainly valid for all types of sediments). Rather, these should be considered as geochemical indicators that depend on time and environment. These Leg 105 sites also confirm that sedimentation rates can be estimated, provided the continental and margin influences are negligible. Indeed, at Site 647 in the southeastern central Labrador Sea, the regular decrease of ${ }^{230} \mathrm{Th} /{ }^{232} \mathrm{Th}$ ratios downcore can be compared to that observed in North Atlantic deep-sea cores. This reflects minor changes in sedimentation rates. At other sites, more influenced by the surrounding ice fluctuations, major changes in sedimentation rates were observed throughout the sampled sequences. On the whole, both Sites 646 and 645 experienced very high mean sedimentation rates, which in Baffin Bay (Site 645) resulted in a negligible initial ${ }^{230} \mathrm{Th}$-excess (over its parent isotope). Fortunately, in the Labrador Sea, down Greenland slope (Site 646), a large ${ }^{230} \mathrm{Th}-$ excess over the "classical ${ }^{230} \mathrm{Th}$-rain" from the water column exists. This possibly bio-induced excess allows us to evaluate the sedimentation rate changes with some reservations (notably due to possible variations in primary productivity through time, which led to fluctuating initial ${ }^{230}$ Th-excesses). Actually, the most significant outcome of this study concerns the peculiarities of ${ }^{230} \mathrm{Th}$ geochemistry in such marine basins that, despite their depth, constitute marginal-type environments. Ongoing studies on organic matter vs. ${ }^{230} \mathrm{Th}$ contents in surficial sediments from the Labrador Sea should help to clarify these peculiarities.

\section{ACKNOWLEDGMENTS}

B. Ghaleb (GEOTOP, Montréal) participated in the analytical program and M. Laithier is responsible for the art.. We also thank the Cochief Scientists of Leg 105, M. Arthur and S. Srivastava (the latter also Chief Scientist during the Hudson's Site 647 survey), who kindly devoted ship time to piston coring of surficial sediments. Special thanks also to A. de Vernal, participating scientist during both Leg 105 and the Hudson site surveys, who sampled the studied cores for us and provided helpful scientific comments. EMR-Canada support to the Ocean Drilling Program, financial assistance from NSERC-Canada (Grants A-9156 and CSP-Leg 105), and FCAR Funds of Québec (Grant EQ-492) were essential.

\section{REFERENCES}

Aksu, A. E., and Piper, D.J.W., 1979. Baffin Bay in the past 100,000 years. Geology, 7:245-248.

Baturin, G. N., 1973. Uranium in the modern marine sedimentary cycle. Geochim. Int., 12:1031-1041.

Beveridge, T. J., Meloche, J. D., Fyfe, W. S., and Murray, R.G.E., 1983. Diagenesis of metals chemically complexed to bacteria: laboratory formation of metal phosphates, sulphides and organic condensates in artificial sediments. Appl. Env. Microbiol., 45:10941108. 
Cochran, J. K., 1982. The oceanic chemistry of U- and Th-series nuclides. In Ivanovich, M., and Harmon, R. S. (Eds.), Uranium Series Disequilibrium: Applications to Environmental Problems: Oxford (Clarendon Press), 384-440.

de Vernal, A., 1986. Analyses palynologiques et isotopiques de sédiments de la mer du Labrador et de la baie de Baffin: eléments d'une climatostratigraphie du Quaternaire Supérieur dans l'est du Canada [Ph.D. dissert.]. Univ. de Montréal, Montréal, Québec, 1-214.

de Vernal, A., and Hillaire-Marcel, C., 1987. Eléments d'une climatostratigraphie du Pléistocène moyen et tardif dans l'est du Canada par l'analyse palynologique et isotopique du forage 84-030-003. Can. J. Earth Sci., 24:1886-1902.

de Vernal, A., Hillaire-Marcel, C., Aksu, A. E., and Mudie, P. J., 1987. Palynostratigraphy and chronostratigraphy of Baffin Bay deep-sea cores: climatostratigraphic implications. Palaeogeogr., Palaeoclimatol., Palaeoecol., 61:97-105.

Fisher, N. S., Teyssié, J.-L., Krishnaswami, S., and Baskaran, M., 1987. Accumulation of $\mathrm{Th}, \mathrm{Pb}, \mathrm{U}$, and $\mathrm{Ra}$ in marine phytoplankton and its geochemicalsignificance. Limnol. Oceanogr., 32:131-142.

Goldberg, E. D., and Koide, M., 1958. Ionium-thorium chronology in deep-sea sediments of the Pacific. Science, 128:1003.

1962. Geochronological studies of deep-sea sediments by the ionium/thorium method. Geochim. Cosmochim. Acta, 26:417-450.

Hillaire-Marcel, C., and Causse, C., in press. Chronologie Th/U des concrétions calcaires des varves du lac glaciaire de Deschaillons (Wisconsinien inférieur). Can. J. Earth Sci.

Holmes, C. W., Osmond, J. K., and Goodel, H. G., 1968. The geochronology of foraminiferal ooze deposits in the Southern Ocean. Earth Planet. Sci. Lett., 4:368-374.

Ivanovich, M., and Harmon, R. S., 1982. Uranium Series Disequilibrium: Applications to Environmental Problems: Oxford (Clarendon Press), 1-571.

Kalil, E. K., 1976. Climate controlled uranium distribution in Atlantic Ocean Core V29-179. In Berger, R., and Suess, H. E. (Eds.), Radiocarbon Dating, Proc. Ninth Int. Conf.: Los Angeles and La Jolla (Univ. of California Press), 95-101.

$\mathrm{Ku}$, T. L., 1966. Uranium series disequilibrium in deep-sea sediments [Ph.D. dissert]. Columbia University, New York.

Ku, T. L., Knauss, K. G., and Mathieu, G. G., 1977. Uranium in open ocean: concentration and isotopic composition. Deep-Sea Res., 24: 1005-1017.

Lally, C., 1982. Chemical procedures. In Ivanovich, M., and Harmon, R. S. (Eds.), Uranium Series Disequilibrium: Applications to Environmental Problems: Oxford (Clarendon Press), 79-106.
Lalou, C., 1982. Sediments and sedimentation processes. In Ivanovich, M., and Harmon, R. S. (Eds.), Uranium Series Disequilibrium: Applications to Environmental Problems: Oxford (Clarendon Press), 431-458.

1985. Les méthodes de datation par les déséquilibres dans les familles de l'uranium. In Roth, E., and Poty, B. (Eds.), and Ménager, M.-Th. (Coll.), Méthodes de Datation par les Phénomènes Nucléaires Naturels, Applications: Paris (Collection CEA, Masson), 175-201.

Mann, H., and Fyfe, W. S., 1984. An experimental study of algal uptake of $\mathrm{U}, \mathrm{Ba}, \mathrm{V}, \mathrm{Co}$ and $\mathrm{Ni}$ from dilute solutions. Chem. Geol., 44: 385-398.

Moreira-Nordemann, L. C., 1980 . Use of ${ }^{234} U /{ }^{238} U$ disequilibrium in measuring chemical weathering rate of rocks. Geochim. Cosmochim. Acta, 44:103-108.

Picciotto, E., and Wilgain, S., 1954. Thorium determination in deepsea sediment. Nature, 173:632-633.

Piggott, C. S., and Urry, W. D., 1939. The radium content of an ocean bottom core. J. Washington Acad. Sci., 29:405-415. 1942. Time relations in ocean sediments. Bull. Geol. Soc. Am., 53:1187-1210.

Rosholt, J. N., Doe, B. R., and Tatsumoto, M., 1966. Evolution of the isotopic composition of uranium and thorium in soil profiles. Bull. Geol. Soc Am., 77:987-1004.

Thurber, D. L., 1962. Anomalous ${ }^{234} \mathrm{U} /{ }^{238} \mathrm{U}$ in nature. J. Geophys. Res., 67:4518-4520.

Turekian, K. K., and Bertine, K. K., 1971a. Deposition of molybdenum and uranium along the major ocean ridge systems. Nature, 229:250251.

Turekian, K. K., and Chan, L. H., 1971b. The marine geochemistry of the uranium isotopes, ${ }^{230} \mathrm{Th}$ and ${ }^{231} \mathrm{~Pa}$. In Brunfeldt, A. 0., and Steinnes, E. (Eds.), Activation Analysis in Geochemistry and Cosmochemistry: Oslo (Universitetsforlaget), 311-320.

Veeh, H. H., 1967. Deposition of uranium from the ocean. Earth Planet. Sci. Lett., 3:145-150.

Date of initial receipt: 9 November 1987

Date of acceptance: 13 June 1988

Ms 105B-155 


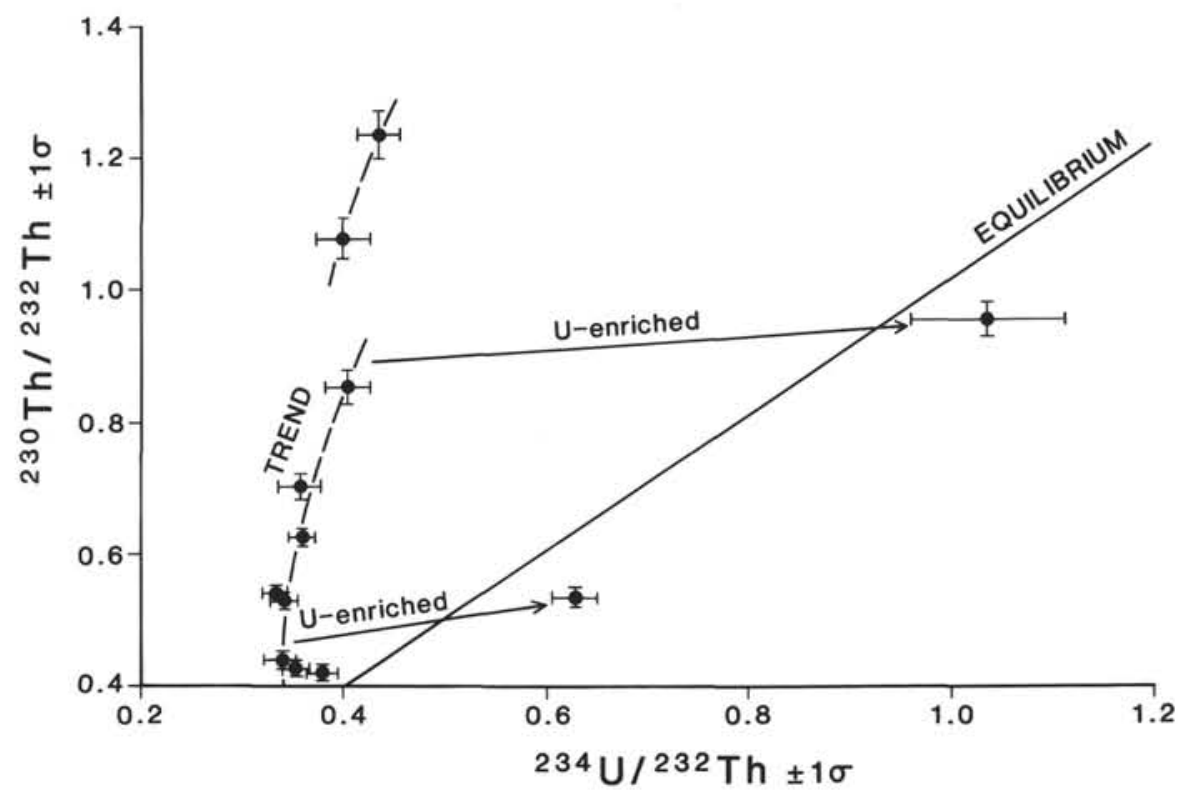

Figure 4. The ${ }^{230} \mathrm{Th} /{ }^{232} \mathrm{Th}$ vs. ${ }^{234} \mathrm{U} /{ }^{232} \mathrm{Th}$ activity ratio variations down Core HU-84-030-003, collected during the Hudson Site 647 survey.

Table 2. Thorium and uranium concentrations and isotope activity ratios at Site 646.

\begin{tabular}{|c|c|c|c|c|c|c|c|c|c|}
\hline $\begin{array}{c}\text { Field } \\
\text { number }\end{array}$ & $\begin{array}{c}\text { Laboratory } \\
\text { number }\end{array}$ & $\begin{array}{l}{ }^{232} \mathrm{Th} \\
(\mu \mathrm{g} / \mathrm{g})\end{array}$ & $\begin{array}{l}{ }^{238} \mathrm{U} \\
(\mu \mathrm{g} / \mathrm{g})\end{array}$ & $\frac{{ }^{234} U}{{ }^{238} U}$ & $\frac{{ }^{238} \mathrm{U}}{{ }^{232} \mathrm{Th}}$ & $\frac{{ }^{230} \mathrm{Th}}{{ }^{232} \mathrm{Th}}$ & $\frac{{ }^{234} \mathrm{U}}{{ }^{232} \mathrm{Th}}$ & $\begin{array}{c}{ }^{230} \mathrm{Th} \\
(\mathrm{dpm} / \mathrm{g})\end{array}$ & $\begin{array}{c}{ }^{234} \mathrm{U} \\
(\mathrm{dpm} / \mathrm{g})\end{array}$ \\
\hline \multirow[t]{2}{*}{ 646B-1-1 } & UQT-664 & 4.10 & 0.48 & 0.95 & 0.36 & 1.34 & 0.34 & 1.35 & 0.34 \\
\hline & & \pm 0.12 & \pm 0.01 & \pm 0.03 & \pm 0.01 & \pm 0.03 & \pm 0.01 & \pm 0.04 & \pm 0.01 \\
\hline \multirow[t]{2}{*}{$646 \mathrm{~B}-1-3$} & UQT-665 & 4.24 & 0.55 & 0.93 & 0.40 & 1.28 & 0.37 & 1.33 & 0.38 \\
\hline & & \pm 0.12 & \pm 0.01 & \pm 0.03 & \pm 0.01 & \pm 0.03 & \pm 0.01 & \pm 0.04 & \pm 0.01 \\
\hline \multirow[t]{2}{*}{$646 \mathrm{~B}-1-4$} & UQT-666 & 2.81 & 0.45 & 1.05 & 0.49 & 1.21 & 0.51 & 0.84 & 0.35 \\
\hline & & \pm 0.09 & \pm 0.01 & \pm 0.03 & \pm 0.02 & \pm 0.04 & \pm 0.02 & \pm 0.03 & \pm 0.01 \\
\hline \multirow[t]{2}{*}{$646 \mathrm{~B}-2-3$} & UQT-668 & 3.17 & 1.14 & 1.10 & 1.09 & 1.74 & 1.20 & 1.36 & 0.94 \\
\hline & & \pm 0.09 & \pm 0.02 & \pm 0.03 & \pm 0.04 & \pm 0.05 & \pm 0.04 & \pm 0.04 & \pm 0.02 \\
\hline \multirow[t]{2}{*}{$646 \mathrm{~B}-1-6$} & UQT-667 & 2.66 & 0.33 & 0.83 & 0.38 & 1.28 & 0.32 & 0.84 & 0.21 \\
\hline & & \pm 0.08 & \pm 0.01 & \pm 0.04 & \pm 0.02 & \pm 0.04 & \pm 0.01 & \pm 0.02 & \pm 0.01 \\
\hline \multirow[t]{2}{*}{$646 \mathrm{~B}-2-4$} & UQT-669 & 2.63 & 0.80 & 1.00 & 0.92 & 1.44 & 0.92 & 0.93 & 0.60 \\
\hline & & \pm 0.09 & \pm 0.02 & \pm 0.03 & \pm 0.04 & \pm 0.04 & \pm 0.04 & \pm 0.03 & \pm 0.01 \\
\hline \multirow[t]{2}{*}{$646 \mathrm{~B}-2-5$} & UQT-670 & 3.64 & 0.90 & 1.13 & 0.75 & 1.13 & 0.85 & 1.01 & 0.76 \\
\hline & & \pm 0.11 & \pm 0.02 & \pm 0.03 & \pm 0.03 & \pm 0.04 & \pm 0.03 & \pm 0.03 & \pm 0.02 \\
\hline \multirow[t]{2}{*}{ 646B-2-6 } & UQT-671 & 4.46 & 0.48 & 0.90 & 0.33 & 0.84 & 0.30 & 0.92 & 0.32 \\
\hline & & \pm 0.13 & \pm 0.01 & \pm 0.03 & \pm 0.01 & \pm 0.02 & \pm 0.01 & \pm 0.03 & \pm 0.01 \\
\hline \multirow[t]{2}{*}{$646 \mathrm{~B}-3-1$} & UQT-672 & 3.24 & 0.91 & 1.06 & 0.85 & 1.03 & 0.90 & 0.82 & 0.72 \\
\hline & & \pm 0.10 & \pm 0.02 & \pm 0.03 & \pm 0.03 & \pm 0.03 & \pm 0.03 & \pm 0.02 & \pm 0.02 \\
\hline \multirow[t]{2}{*}{$646 \mathrm{~B}-3-2$} & UQT-673 & 2.85 & 0.80 & 1.02 & 0.85 & 1.18 & 0.87 & 0.82 & 0.61 \\
\hline & & \pm 0.10 & \pm 0.02 & \pm 0.03 & \pm 0.04 & \pm 0.04 & \pm 0.04 & \pm 0.03 & \pm 0.01 \\
\hline \multirow[t]{2}{*}{$646 \mathrm{~B}-3-4$} & UQT-674 & 2.94 & 0.80 & 1.10 & 0.83 & 1.05 & 0.91 & 0.76 & 0.66 \\
\hline & & \pm 0.09 & \pm 0.02 & \pm 0.03 & \pm 0.03 & \pm 0.03 & \pm 0.04 & \pm 0.02 & \pm 0.02 \\
\hline \multirow[t]{2}{*}{$6 \mathrm{~B} 36-98-10$} & UQT-492 & 6.14 & 0.92 & 1.01 & 0.46 & 0.55 & 0.46 & 0.83 & 0.70 \\
\hline & & \pm 0.40 & \pm 0.02 & \pm 0.03 & \pm 0.03 & \pm 0.01 & \pm 0.03 & \pm 0.05 & \pm 0.02 \\
\hline
\end{tabular}

Error data represent one $\sigma$ from counting statistics. 


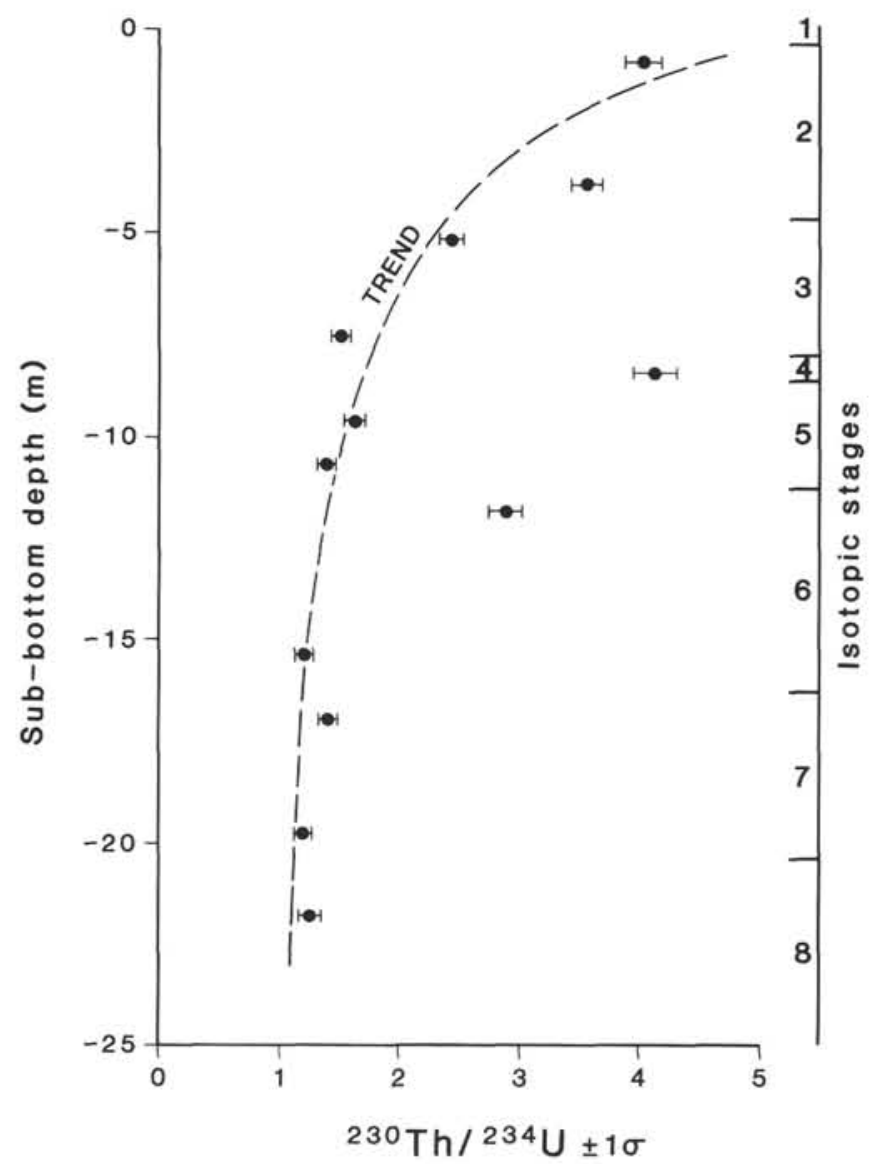

Figure 5. Changes in the ${ }^{230} \mathrm{Th} /{ }^{234} \mathrm{U}$ activity ratios downcore at Site 646.

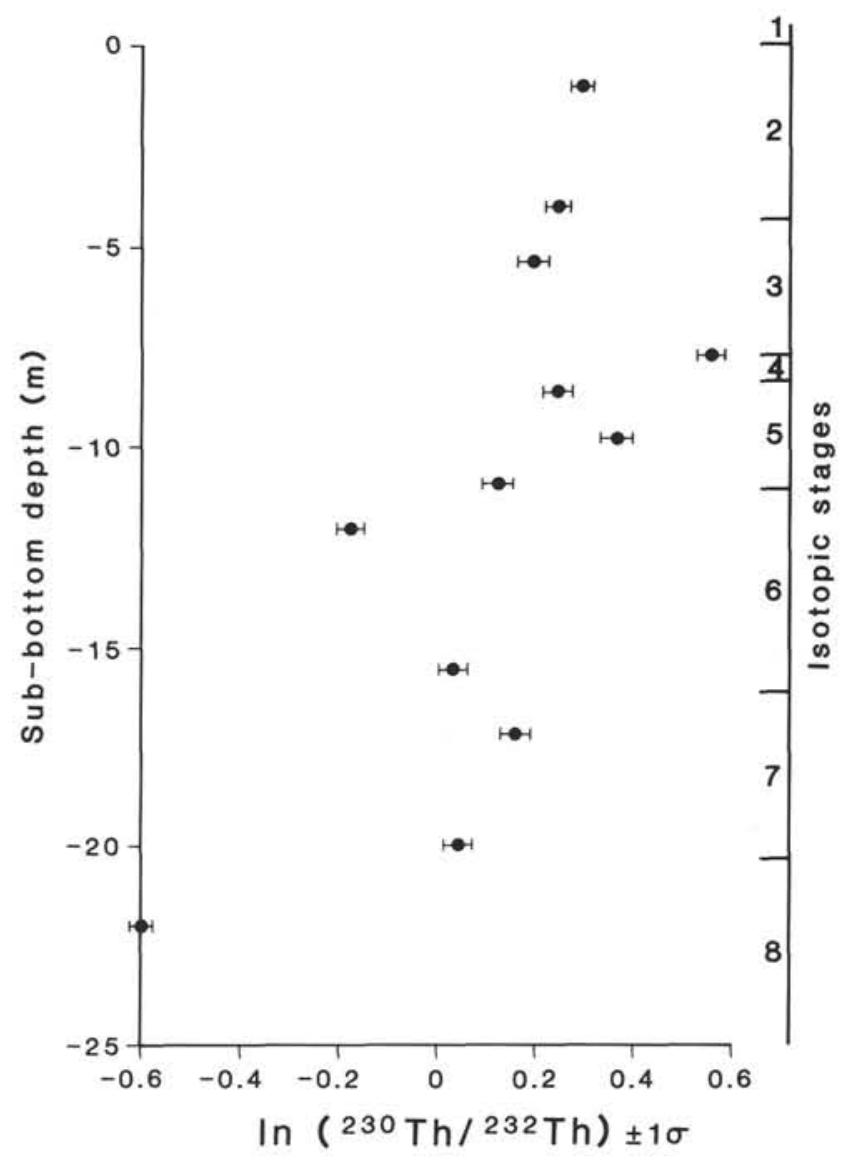

Figure 6. $\log \left({ }^{230} \mathrm{Th} /{ }^{232} \mathrm{Th}\right)$ changes downcore at Site 646. 


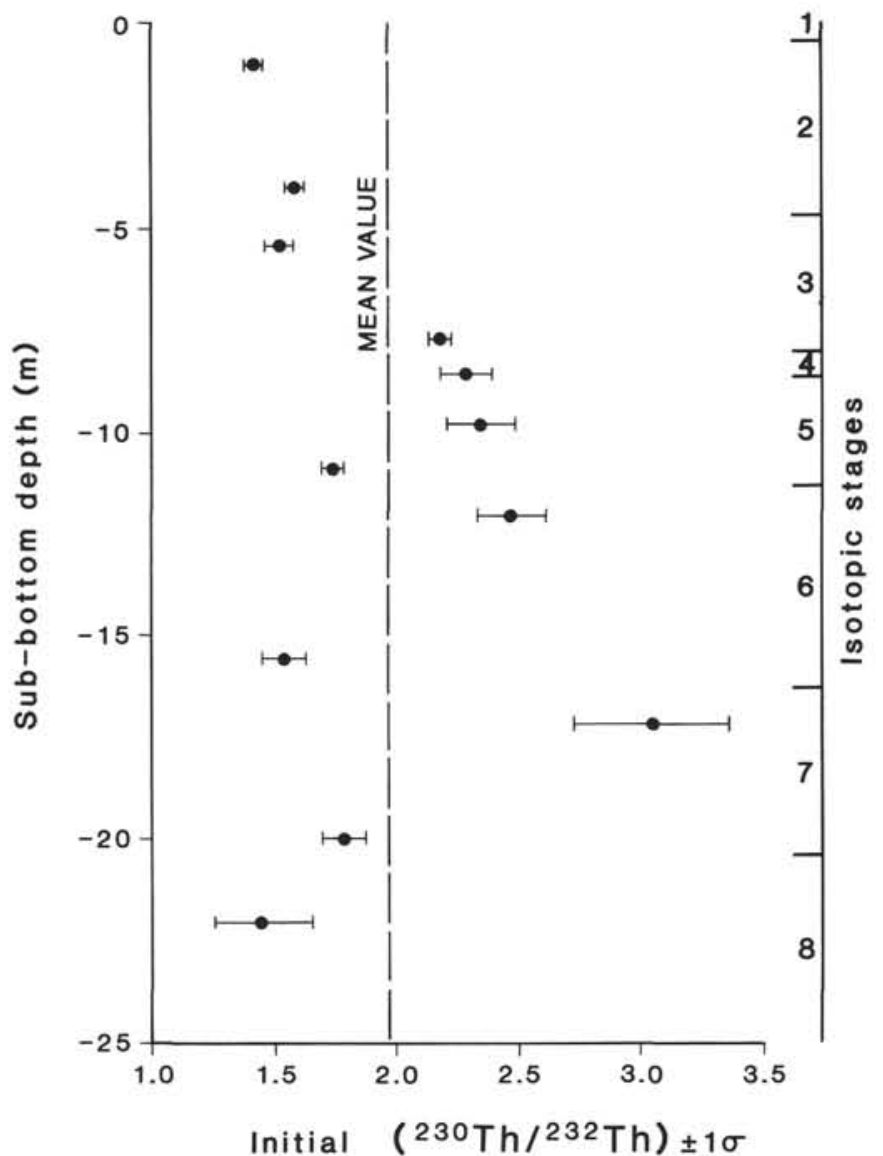

Figure 7. Initial ${ }^{230} \mathrm{Th} /{ }^{232} \mathrm{Th}$ activity ratios downcore at Site 646 , calculated with the time control from ${ }^{18} \mathrm{O}$-stratigraphy.

Table 3. Initial ${ }^{230} \mathrm{Th} /{ }^{232} \mathrm{Th}$ values in sediments from Site 646 calculated using approximative control provided by ${ }^{18} \mathrm{O}$-stratigraphy and indicative values of ${ }^{230} \mathrm{Th}$-excess $/{ }^{232} \mathrm{Th}$ activity ratio and of sedimentation rate changes.

\begin{tabular}{lcccccc}
\hline $\begin{array}{c}\text { Field } \\
\text { number }\end{array}$ & $\begin{array}{c}\text { Laboratory } \\
\text { number }\end{array}$ & $\begin{array}{c}\text { Depth } \\
(\mathrm{cm})\end{array}$ & $\begin{array}{c}\text { Chronology from } \\
18 \text { O-stratigraphy }\end{array}$ & {$\left[\frac{{ }^{230} \mathrm{Th}}{232}\right]^{1}$} & {$\left[\frac{{ }^{230} \mathrm{Th}}{232}\right]^{2}$} & $\begin{array}{c}\text { Sedimentation } \\
\text { rate }(\mathrm{cm} / \mathrm{k} . \mathrm{y} .)^{3}\end{array}$ \\
\hline 646B-1-1 & UQT-664 & 100 & $8,000 \pm 2,000$ & $1.42 \pm 0.02$ & 1.06 & $\sim 12.7$ \\
646B-1-3 & UQT-665 & 400 & $32,000 \pm 3,000$ & $1.59 \pm 0.03$ & 1.23 & $\sim 10.9$ \\
646B-1-4 & UQT-666 & 540 & $40,000 \pm 5,000$ & $1.53 \pm 0.05$ & 1.17 & $\sim 11.5$ \\
646B-2-3 & UQT-668 & 770 & $65,000 \pm 5,000$ & $2.18 \pm 0.05$ & 1.82 & $\sim 7.4$ \\
646B-1-6 & UQT-667 & 860 & $78,000 \pm 5,000$ & $2.29 \pm 0.10$ & 1.93 & $\sim 7.0$ \\
646B-2-4 & UQT-669 & 980 & $110,000 \pm 10,000$ & $2.35 \pm 0.14$ & 1.99 & $\sim 6.8$ \\
646B-2-5 & UQT-670 & 1093 & $130,000 \pm 5,000$ & $1.75 \pm 0.04$ & 1.39 & $\sim 9.7$ \\
646B-2-6 & UQT-671 & 1207 & $150,000 \pm 10,000$ & $2.48 \pm 0.21$ & 2.12 & $\sim 6.3$ \\
646B-3-1 & UQT-672 & 1559 & $180,000 \pm 15,000$ & $1.55 \pm 0.09$ & 1.19 & $\sim 11.3$ \\
646B-3-2 & UQT-673 & 1718 & $215,000 \pm 15,000$ & $3.06 \pm 0.32$ & 2.70 & $\sim 5.0$ \\
646B-3-4 & UQT-674 & 1999 & $220,000 \pm 10,000$ & $1.79 \pm 0.08$ & 1.43 & $\sim 9.4$ \\
6B36-98-10 & UQT-492 & 2200 & $260,000 \pm 20,000$ & $1.44 \pm 0.20$ & 1.08 & $\sim 12.5$ \\
\hline Mean values & & & & $1.95 \pm 0.49$ & $1.6 \pm 0.5$ & $\sim 9$ \\
\hline
\end{tabular}

${ }^{1}$ Extrapolate initial values of ${ }^{230} \mathrm{Th} /{ }^{232} \mathrm{Th}$ activity ratios, calculated according to ${ }^{18} \mathrm{O}$-stratigraphy chronology.

2 Indicative initial values of ${ }^{230} \mathrm{Th}$-excess $/{ }^{232} \mathrm{Th}$ activity ratios, related to "230 $\mathrm{Th}$-rain" (assuming a uniform ${ }^{230} \mathrm{Th} /{ }^{232} \mathrm{Th}$ activity ratio equal to 0.36 for detrital particles).

${ }^{3}$ [mean sedimentation rate from ${ }^{18} \mathrm{O}$ data] $\times$ [mean $\left({ }^{230} \mathrm{Th}\right.$-excess $\left.{ }^{232} \mathrm{Th}\right)$ initial ratio] $\div$ [calculated $\left({ }^{230} \mathrm{Th}\right.$-excess/232 Th) initial ratio].

Error data represent one $\sigma$ from counting statistics. 
C. CAUSSE, C. HILlAIRE-MARCEL

Table 4. Thorium and uranium concentrations and isotope activity ratios at Site 645 .

\begin{tabular}{|c|c|c|c|c|c|c|c|c|c|c|}
\hline $\begin{array}{c}\text { Field } \\
\text { number }\end{array}$ & $\begin{array}{l}\text { Laboratory } \\
\text { number }\end{array}$ & $\begin{array}{l}{ }^{232} \mathrm{Th} \\
(\mu \mathrm{g} / \mathrm{g})\end{array}$ & ${ }_{(\mu \mathrm{g} / \mathrm{g})}^{{ }^{238} \mathrm{U}}$ & $\frac{{ }^{234} U}{{ }^{238} U}$ & $\frac{{ }^{238} \mathrm{U}}{{ }^{232} \mathrm{Th}}$ & $\frac{{ }^{230} \mathrm{Th}}{{ }^{232} \mathrm{Th}}$ & $\frac{{ }^{234} \mathrm{U}}{{ }^{232} \mathrm{Th}}$ & $\begin{array}{c}{ }^{230} \mathrm{Th} \\
(\mathrm{dpm} / \mathrm{g})\end{array}$ & $\begin{array}{c}{ }^{234} \mathrm{U} \\
(\mathrm{dpm} / \mathrm{g})\end{array}$ & $\begin{array}{l}\text { Depth } \\
\text { (cm) }\end{array}$ \\
\hline \multirow[t]{2}{*}{$645 \mathrm{~A}-1-1$} & UQT-675 & 8.32 & 1.21 & 0.97 & 0.44 & 1.63 & 0.43 & 3.34 & 0.88 & 2 \\
\hline & & \pm 0.41 & \pm 0.03 & \pm 0.03 & \pm 0.02 & \pm 0.04 & \pm 0.02 & \pm 0.16 & \pm 0.02 & \\
\hline \multirow[t]{2}{*}{5 G14-59-61 } & UQT-490 & 24.12 & 2.06 & 1.05 & 0.26 & 0.36 & 0.27 & 2.11 & 1.61 & 660 \\
\hline & & \pm 7.24 & \pm 0.06 & \pm 0.03 & \pm 0.08 & \pm 0.01 & \pm 0.08 & \pm 0.64 & \pm 0.05 & \\
\hline \multirow[t]{2}{*}{5 G14-59-61 } & UQT-503 & 17.29 & 1.73 & 0.99 & 0.30 & 0.35 & 0.30 & 1.49 & 1.27 & 660 \\
\hline & & \pm 1.07 & \pm 0.19 & \pm 0.12 & \pm 0.04 & \pm 0.01 & \pm 0.04 & \pm 0.09 & \pm 0.14 & \\
\hline \multirow[t]{2}{*}{$5 F 32-34-36$} & UQT-488 & 10.80 & 2.32 & 1.01 & 0.65 & 0.51 & 0.66 & 1.34 & 1.74 & 1500 \\
\hline & & \pm 2.66 & \pm 0.05 & \pm 0.02 & \pm 0.16 & \pm 0.01 & \pm 0.16 & \pm 0.33 & \pm 0.04 & \\
\hline \multirow[t]{2}{*}{$5 F 35-76-78$} & UQT-491 & 10.95 & 1.66 & 1.16 & 0.46 & 0.53 & 0.53 & 1.42 & 1.43 & 2000 \\
\hline & & \pm 2.17 & \pm 0.05 & \pm 0.03 & \pm 0.09 & \pm 0.01 & \pm 0.11 & \pm 0.28 & \pm 0.04 & \\
\hline \multirow[t]{2}{*}{$5 F 35-76-78$} & UQT-504 & 10.77 & 2.19 & 0.85 & 0.62 & 0.53 & 0.52 & 1.41 & 1.38 & 2000 \\
\hline & & \pm 0.45 & \pm 0.27 & \pm 0.13 & \pm 0.08 & \pm 0.01 & \pm 0.07 & \pm 0.06 & \pm 0.18 & \\
\hline
\end{tabular}

Error data represent one $\sigma$ from counting statistics.

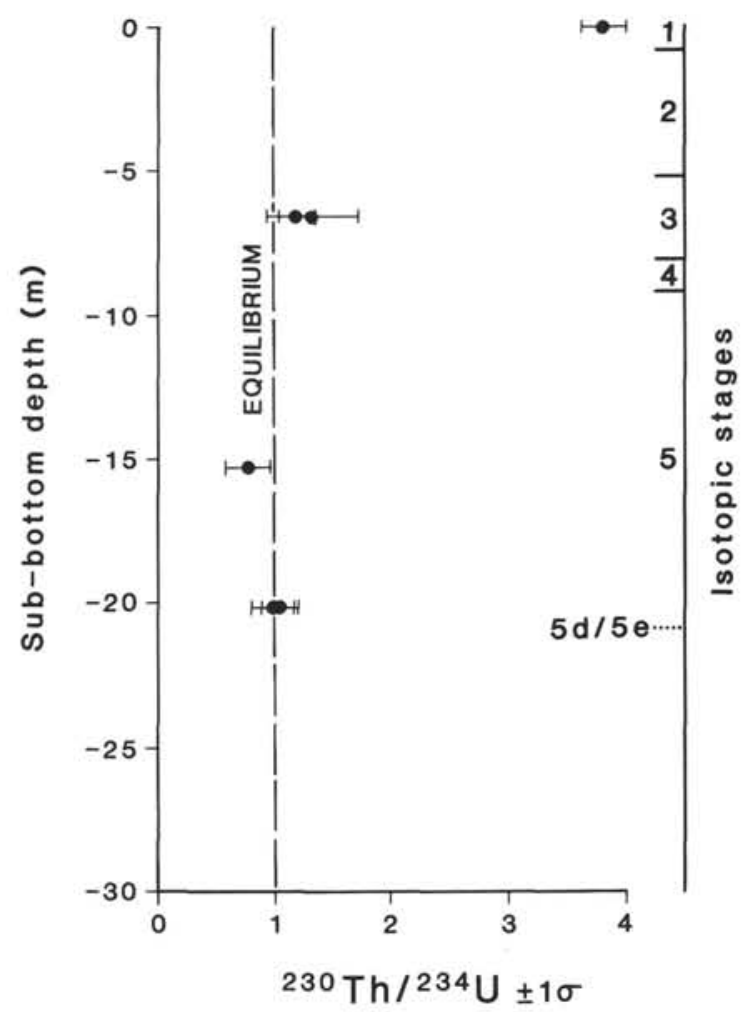

Figure 8.The ${ }^{230} \mathrm{Th} /{ }^{234} \mathrm{U}$ activity ratios downcore at Site 645 . 